\title{
The Development of Agricultural Cooperatives in Ethiopia: History and a Framework for Future Trajectory \\ Dagne Mojo ${ }^{1}$, Terefe Degefa ${ }^{2}$ and Christian Fischer ${ }^{3}$
}

\begin{abstract}
Cooperatives have been playing important roles in the socio-economic lives of communities for a long time during which they have also encountered challenges and weaknesses. These have made countries to have their own distinct histories of the development of cooperatives and of course sometimes having similarities. Based on a critical review of literature and analysis of secondary data, this article presents a brief history of the development of the Ethiopian cooperatives with a focus on agricultural cooperatives. It indicates that although modern cooperatives have rapidly increased and positively contributed to community development, several weaknesses and challenges still remain being rooted in the economic, social, institutional, political and environmental settings. Due to the importance given to agricultural cooperatives in today's Ethiopia, sustaining the contributions of cooperatives to members and the larger community becomes vital that deserves policymakers' attention. Towards that end and based on the key findings, the article proposes a framework that can help integrate sustainability principles into a cooperative structure right from the setup stage, as a future trajectory in the development of cooperatives in Ethiopia.
\end{abstract}

Keywords: agricultural cooperatives, collective action, developing country, Ethiopia, sustainable development, framework

1 Postdoc Research Fellow, UN Environment - International Ecosystem Management Partnership (UNEP-IEMP), C/O Institute of Geography and Natural Resources Research, Chinese Academy of Sciences (CAS), Beijing, China; Email: dagnemojo@yahoo.com.au

2 Associate Professor, Center for Population Studies, College of Development Studies, Addis Ababa University

${ }^{3}$ Faculty of Science and Technology, Free University of Bozen-Bolzano, Bolzano, Italy; Email: Christian.Fischer@unibz.it 


\section{Introduction}

The practice of cooperation to solve mutual problems through organized and coordinated efforts has a long history in Ethiopia. Cooperation exists within the wide variety of institutional and organizational landscapes, such as public and civil society organizations, private companies and industries, and traditional and partybased governance institutions, etc. (Lemma 2009). Parallel to the modern way of cooperation, traditional collective action associations have also been playing a vital role among rural and urban communities.

Collective action groups, in particular, modern cooperatives, have gained due attention in development discourse and programs designed for poverty reduction in Ethiopia (Emana 2012). The Ethiopian government believes cooperatives as important vehicles for the implementation of different development programs mainly in the agricultural sector (Emana and Nigussie 2011, Alemu 2012, MoA 2012), since agriculture which is dominated by smallholder farmers determines the growth of all other sectors and consequently of the entire economy in Ethiopia (Gebre-selassie and Bekele 2012, MoA 2012). Cooperatives may also provide some non-economic benefits as they are claimed to be an alternative organizational model for sustainable development and well-being of the society where economic, social, and environmental factors are inherently interdependent (Wanyama 2014).

There is a scarcity of systematic, well organized, and updated literature on the subject of cooperative movement and its impacts due to several reasons. In the case of Ethiopia, however, there have also been gaps in documentation because of lack of smooth flow of information from lower to higher government levels, and misplacement of documents on cooperatives resulting from the continuous restructuring of government institutions at different periods (Lemma 2009).

The fast expanding trend of cooperative establishment in the country in recent years has also been accompanied, only by limited studies some of which indicate un-sustainability of cooperatives in the long run. In this regard, Bernard et al. (2013) and Mojo et al. (2015a) indicate that the undifferentiated services of cooperatives to members and non-members, low participation of members, and a long hand of government on the development of cooperatives, have caused a great concern regarding the autonomous existence of cooperatives in the long run if in case government halts its support. A limited number of studies on environmental impacts of cooperatives though not of much significance, however, exist. For instance, Stellmacher and Grote (2011) and Mojo et al. (2015b) studies focus on a negative effect of some agricultural cooperatives in Ethiopia.

\section{Aim and Method}

The major aim of this article is to review the development of agricultural cooperatives and impacts in Ethiopia in order to propose a framework that can help 
mainstream social, economic and environmental considerations when establishing agricultural cooperatives, and carry out evaluations to check cooperative performances and impacts in the future. Regarding method, literatures required to achieve the aim of this article were collected from academic journal databases using relevant key words in the internet based search engines, while secondary data and published reports were obtained from the Federal Cooperative Agency (FCA) of Ethiopia. Secondary data were analysed and interpretations were made to reveal the empirical basis of, for instance, the development of primary cooperatives and trends and status of primary cooperatives in Ethiopia. Leading theories and literature were utilized to construct the Sustainability Planning, Monitoring, and Evaluation (SPME) Framework.

The remaining sections of the article are organized as follows. Next section presents the reviews of historical evolution, legal frameworks, types, trends, and status of modern cooperatives in Ethiopia. While the third section recapitulates some findings about the economic, social and environmental impacts of agricultural cooperatives, section four highlights strengths, weaknesses, opportunities and threats to the cooperative movement in the country. The penultimate section proposes a Sustainability Planning, Monitoring and Evaluation (SPME) framework that can help integrate sustainable development principles into a cooperative system beginning from the setup stage. The last section presents concluding remarks.

\section{The Development of Cooperatives in Historical Setting}

This section presents a brief historical note on cooperative development in Ethiopia. The logical step towards that direction is to assess how successive Ethiopian regimes have advocated the notion and practice of cooperation in the country.

\section{Cooperatives during Emperor Haile-Selassie I (1932-1974)}

Since ancient time, Ethiopians are used to carrying out agricultural activities, trade and military operations through the traditional types of cooperative efforts (Veerkumaran 2007). However, the modern cooperatives in Ethiopia had not evolved unfortunately from their predecessor traditional associations, but rather modified from the Western cooperative philosophy and were first introduced during the Imperial era (Bernard et al. 2010, Veerkumaran 2007). They were first informally introduced during the Italian invasion (1936-1941), and later the American Peace Corps volunteers established a consumers' association in 1943 (FCA 2014a).

Subsequently, the first formal legislative Farm Workers Cooperatives Proclamation No.44/1960 was declared in 1960. The major mentioned causes for the establishment of a legal framework were an increased unemployment rate, rural 
to urban migration and challenges to government regarding land use policy, etc. (FCA 2015). The government tried to steadfastly use cooperatives as a tool to overcome such problems through expanding modern farming systems, and putting individual land holdings under the control of cooperatives.

Cooperatives were also primarily used as tools to overcome the shortage of foreign currencies by supporting the production and export of high value commercial crops, like coffee (Bernard et al. 2010 and FCA 2014a). Cooperative membership consisted of farmers with large landholdings that tended to exclude smallholders. The services of the cooperatives were also limited to richer farmers and to cash crop growing areas while the poor farmers and other areas were discriminated against (Bernard et al. 2010; Teka 2011). Additionally, the first legislation was only for agricultural cooperatives. Other shortcomings were problems related to lack of awareness among government organizations, low implementation capacity, lack of supportive laws and problems with the existing land tenure system (Veerkumaran 2007).

To improve some of the problems observed during the first few years of implementation, the second Proclamation (No.241/1966) was introduced in 1966 (Teka 2011). Based on this proclamation, five types of cooperatives (multipurpose, saving and credit, consumers, artisans and farm workers) were established. Government employees such as those in the Ethiopian Airlines, the former Ethiopian Electric Light and Power Authority, the Commercial Bank, the Highway Authority and Telecommunications were given the opportunities to legally organize savings and credit cooperatives (Lemma 2009).

According to Veerkumaran (2007), the government contributed to the development of the Ethiopian cooperative movement by familiarizing the modern cooperative concept and establishing an independent authority and regulatory body that registers, audits, and serves as a cooperative court. It also established a training institution-the community development training and demonstration centre (in Hawassa town), and arranged a national cooperative investment fund administered by a special cooperative credit section of the Development Bank of Ethiopia. By the end of the imperial era, there were a total of 149 such cooperatives in the country: 94 being multipurpose, 19 savings and credit, 19 consumers and 17 handicrafts (Lemma 2009 and Bernard et al. 2010).

However, such cooperatives of the Imperial time not only had their own limitations but also failed to be in line with international cooperative principles ${ }^{4}$.

\footnotetext{
${ }^{4}$ International cooperative principles include voluntary and open membership; democratic member control; members' economic participation; autonomy and independence; provision of education, training and information; cooperation among cooperatives; and concern for the community (ICA 2014). Usually three basic principles: user-owned, user-controlled and user-benefiting are adopted by cooperatives.
} 
For instance, membership was neither open nor voluntary; cooperative establishment was top-down (not based on a community initiative) and, in particular, producers' cooperatives mainly benefit the government (FCA 2014a). Hence, they failed to survive in the succeeding regime.

\section{Cooperatives during the Derg (Committee) Regime (1974-1991)}

The Military Government known as the Derg, noted as socialist regime, abolished all types of formal cooperatives (except the urban saving and credit cooperatives) established during the Imperial era. Subsequently, the regime organized new types of cooperatives based on the Marxist principles aimed at ending the exploitation of the peasantry by the Monarchical feudal system (Kodama 2007 and Bernard et al. 2010). Moreover, the cooperative ideology of the Derg regime was also different from the modern cooperative principles (Kodama 2007). The Derg regime gave special attention to cooperatives as instruments for mass movement, equitable resources mobilization and distribution (as part of land reform), for the purpose of constructing a particular brand of socialism in the countryside (Abebaw and Haile 2013). Generally, the Derg regime used cooperatives to organize peasants, control the prices of commodities, levy taxes, and extend government control to the local level (Teka 2011).

Similar to the Imperial regime, the Derg also enacted different cooperative proclamations to realize its philosophy. The first legalizing proclamation that clearly stated the objectives, powers and duties of cooperatives was proclamation No. 71/1975 on the base of which three types of rural associations were established. These are: (1) Peasant Associations-the lowest administrative structures where membership was obligatory for farmers; (2) Agricultural Producer Cooperatives-established to provide preferential treatment to smallholders; and (3) Service Cooperatives-marketing and purchasing cooperatives that handled modern inputs, credits, milling services, consumer goods and peasants' produce (Kodama 2007).

Since the first proclamation (No. 71/1975) was only targeting agricultural cooperative societies, Cooperative Societies Proclamation No. 138/1978 was enacted to include other types of cooperatives, like housing, thrift and credit, handicrafts and others. In fact, the major aims of this proclamation were to bring about "Socialist Agricultural Transformation" in rural areas, and a "Socialist Marketing System" in both rural and urban areas (FCA 2014a). Even though many efforts were made to restructure cooperative movement based on these proclamations, the government rather ended up with further direct control of cooperatives and turning them into government political use instead of making them development instruments (Veerkumaran 2007 and Teka 2011).

During this centrally controlled economy, a large number of cooperatives 
emerged, the peak being 10,524 primary cooperatives (of which $80 \%$ were agricultural cooperatives) with 4,529,259 members (Lemma 2009 and FCA 2014a). However, the established cooperatives encountered various organizational, operational, leadership, production and distribution problems due to passive participation, carelessness on the part of the members and the embezzlement of cooperative resources by its leadership, which was being appointed by political cadres (Bernard et al. 2010). This source notes that, being forced by socioeconomic and political instabilities in the country, the Derg regime introduced a mixed economic policy in March 1990. The policy states, "any cooperatives can legally dissolve if its general assembly decides." Subsequently, almost all producer cooperatives and some service cooperatives in rural areas were legally dismantled throughout the country.

In summary, the movement of cooperatives (agricultural and others) during the Derg regime was characterized: as state driven, with mandatory membership, appointed (by the ruling party) boards of directors and managers (Teka 2011). In fact, the state itself was characterized in owning and controlling the major means of production, including rural and urban lands, and basic production and distribution facilities (Asrat and Shiferaw 2009). Thus, cooperatives of the Derg regime were not based on strong foundations, like the Imperial era, and as a result were not sustainable.

\section{The EPRDF Cooperative Movement (1991-Present)}

In May 1991, the current ruling EPRDF (Ethiopian People's Revolutionary Democratic Front) "overthrew" the communist Derg regime. Consequently, during the transition period the local people vandalized most of the service cooperatives for their assets. Since cooperatives were perceived as communist institutions that have no place in the new "free economy" of the EPRDF, nobody was interested to rescue the property of the cooperatives when thieves, dissatisfied and corrupted management members looted and dismantled them (Kodama 2007 and Bernard et al. 2010). The new government also viewed cooperatives as mechanisms for corruption, servicing the violent regime of the past, which accounted for many cooperative organizers being thrown into jail (Holmberg 2011). According to Holmberg, the cooperatives of the Derg regime ended with harboured resentments and violence, coupled with the loss of faith in the cooperative idea due to the tragic ending of cooperatives of the socialist era.

After the downfall of the Derg, the new government (EPRDF) had taken some years to change its view of cooperatives and to shift the mind-set (Holmberg 2011). Some "cooperative activists" and organizers assisted the government to reconsider the cooperatives positively. Holmberg points out that the International Labor Organization (ILO) also played key roles in the renaissance of the cooperatives in Ethiopia, by organizing study tours for cooperative activists and 54 
leaders to strengthen their understanding and leadership skills through sharing the experiences of the neighbouring countries. By the mid-1990s the government's view of cooperatives had changed and policymakers generally accepted the meanings and principles of cooperatives given by the International Cooperative Alliance (ICA) in 1995 (FCA 2015).These efforts led to the establishment of cooperative legislations that consequently opened up a room for the flourishing of modern cooperatives in Ethiopia.

\section{The Legal Framework of the Current Ethiopian Cooperative System}

The new era of the cooperative movement in Ethiopia started with a new Agricultural Cooperative Society Proclamation No 85/1994 in 1994 (Abebaw and Haile 2013). This proclamation states that "the government sets convenient conditions for the peasants living in rural areas to be organized freely and willingly to jointly solve their economic and social problems through pulling their resources." Unlike the past two regimes, the EPRDF government opened a legal space to organize cooperatives voluntarily, democratically and within a market setting.

Though this proclamation (No. 85/1994) helped to reorganize farmers on a voluntary basis to establish new cooperatives or to reorganize and strengthen the old ones, the organizers had a hard time to change peoples' attitude towards cooperatives due to the bad image of the cooperatives of the Derg regime (Holmberg 2011). As further indicated by this same source, the initiators started with demonstration projects where the members started sharing dividends after a year that somehow helped to promote the benefit of the cooperatives to change the attitude towards them.

Similar to the past two regimes, the first cooperative society proclamation (No 85/1994) of EPRDF was also only targeting the agricultural cooperatives and lacks sufficient details. Hence, the government enacted the second proclamation (No. 147/1998) in 1998. This proclamation outlined the layers of organizational structure of the cooperatives into primary cooperatives, unions, federations, and cooperative leagues that can foster broader growth of the movement (FDRE 1998 and Kodama 2007).The proclamation also specified related organs of the cooperatives that include members, a general assembly, a special resolution, and a management committee with clear roles and responsibilities. Besides, it indicated the possible formation of an appropriate authority, such as a government organ ${ }^{5}$ established at federal, regional, or a local bureaus level. This government organ

\footnotetext{
${ }^{5}$ This government organ was first established in 2002 by Proclamation No. 274/2002, and was called the Federal Cooperative Commission (FCC) and later named the Federal Cooperative Agency (FCA). Until now, FCA is in charge of promoting cooperatives in Ethiopia.
} 
can organize and register cooperative societies, provide training and other technical assistance, and conduct research on cooperative societies.

Proclamation No. 147/1998 also emphasised on the payment system, i.e., that the cooperative unions should deduct $30 \%$ of the net profit and divide the remaining $70 \%$ among member cooperatives, while the member cooperatives, in turn, pay $70 \%$ of their profit to cooperative members as dividends. Furthermore, the proclamation mandated every cooperative society to have bylaws that should be formulated and accepted by the members themselves (FDRE 1998).

While Proclamation No. 147/1998 is the backbone of the current cooperative society and cooperative movement in the country, there was (minor) amendment to this proclamation through Cooperative Society Proclamation (Amendment) No. 402/2004 in 2004. The amendment mostly aimed at strengthening membership incentives by improving their rights, for instance by allowing a cooperative society that faces shortage of capital to sell certain shares to a person who is not a member without contradicting the principle of the cooperative. This further opens up a room to mobilize capital, although not yet implemented (Alemu et al. 2011).

Following the legal framework and strong promotion, several cooperative societies were established both in rural and urban areas. The Ethiopian government has also been formulating different development policies and strategies that support and strengthen cooperative movements, particularly since 2002 (FCA 2014a). As a result, currently more than 60 thousand primary cooperatives with more than nine million members exist and own a total capital of more than 11.3 billion Ethiopian Birr (FCA 2015).

Nevertheless, the revolution of new cooperative was not without criticism mainly, due to the strong involvement of the government from the viewpoint of the Western concepts of cooperatives and civil society (Kodama 2007), which is still true. As reported by Ruben and Heras (2012), most (74\%) of cooperatives in Ethiopia are initiated by government or non-government organs. Indeed, the long hand of the government in cooperatives is largely due to its development strategy that aims to extend cooperative services such as the supply of production inputs throughout the country.

\section{Objectives, Principles and Values of the Cooperative Society}

Proclamation No.47/1998 states that the cooperative societies shall aim to solve social and economic problems by coordinating their knowledge, wealth, and labour (see details in FDRE 1998). In addition, it also listed the guiding principles of a cooperative society that are similar to the seven cooperative principles established by the International Cooperative Alliance (ICA 2014). The basic principles and values of the contemporary Ethiopian cooperatives are therefore adopted from ICA. However, the question remaining is about the extent of implementation of the principles and realities on the ground in the country namely with the low literacy 
rate of members, poor governance, and low economic performance. In addition, the majority of the cooperatives have been initiated by the government, which indicates its strong interest in cooperative movement, including cooperative governance which by itself raises questions of cooperative independence.

\section{Types, Trends, Current Status and Distributions of Modern Cooperatives}

Despite the existence of modern cooperatives in all the sectors throughout Ethiopia, Proclamation No. 147/1998 underscores, specifically targeted sectors, including Agricultural, Housing, Industrial and Artisans Producers, Consumers, Savings and Credit, Fishery, and Mining Cooperative Societies (FDRE 1998). This proclamation, in fact, allows individuals to be organized according to their interests, as long as their targets are to overcome social and economic problems in the "free-market economy". Consequently, some of the traditional associations, such as Idir (particularly in big towns and cities), have also been legally registered under this proclamation. Regardless of the socioeconomic focus of the proclamation, the modern cooperatives have currently been involved in the area of environmental and natural resource management to overcome related problems in their vicinity.

While several cooperative types are listed in the FCA database, a slight inconsistency in record keeping (regarding the type and number of cooperatives at regional and federal levels) has been observed. This is mostly, due to the existence of some overlapping among some categories and unclear definition of a "type" that has not been used uniformly across regions. The FCA data show that in the categorization of cooperatives by type, "type" is sometimes defined based on specific products (e.g. coffee, fish, etc.), and sometimes based on general activities that cooperatives undertake. For instance, a broad category, agricultural product marketing can overlap with specific product types, such as milk and milk products, coffee, fruits and vegetable producing cooperatives. Similarly, multipurpose cooperatives are also mainly engaged in cereal production and marketing.

To handle these limitations, the types of cooperatives are summarized (Table 1) based on the categories given under Proclamation No. 147/1998. Table 1 also shows the proportion of each type; for instance, agriculture and multipurpose cooperatives which take the largest share $(27 \%$ of all primary cooperatives and $65 \%$ of all members). As a suggestion, the FCA may also need to reconsider the categorization of cooperatives that would be applicable and consistent across the regions of the country. 
Table 1. Summary of primary cooperatives in Ethiopia as of March 2013

\begin{tabular}{|c|c|c|c|}
\hline $\begin{array}{l}\text { Types of } \\
\text { primary } \\
\text { cooperatives }\end{array}$ & Description & $\begin{array}{c}\text { Cooperatives } \\
\text { Number }(\%)\end{array}$ & $\begin{array}{c}\text { Members } \\
\text { Number } \\
(\%)\end{array}$ \\
\hline $\begin{array}{l}\text { Agricultural } \\
\text { and } \\
\text { multipurpose }\end{array}$ & $\begin{array}{l}\text { - All cooperatives based on agricultural } \\
\text { activities (crops, animal, honeybee, } \\
\text { irrigation, seed and fertilizers, etc.). }\end{array}$ & $13,029(27.1)$ & $\begin{array}{r}4,313,318 \\
(65.0)\end{array}$ \\
\hline Fishery & $\begin{array}{l}\text { - Involve in fishing, fish management, } \\
\text { production, marketing, etc. }\end{array}$ & $46(0.1)$ & $3,125(0.1)$ \\
\hline $\begin{array}{l}\text { Natural } \\
\text { Resources and } \\
\text { Tourism }\end{array}$ & $\begin{array}{l}\text { - Involve in environmental protection and } \\
\text { forest management, promoting culture, } \\
\text { tourism business, etc. }\end{array}$ & $319(0.7)$ & $35,469(0.5)$ \\
\hline Consumers & $\begin{array}{l}\text { - Mainly based in urban/suburban, and } \\
\text { rarely in rural areas aiming to supply } \\
\text { consumable items for members at fair } \\
\text { prices. }\end{array}$ & $2,496(5.2)$ & $\begin{array}{r}492,993 \\
(7.4)\end{array}$ \\
\hline $\begin{array}{l}\text { Saving and } \\
\text { credit }\end{array}$ & $\begin{array}{l}\text { - Based at either rural or urban areas, aim to } \\
\text { improve members' saving habits, and to } \\
\text { provide credit services. }\end{array}$ & $11,850(24.6)$ & $\begin{array}{r}1,043,773 \\
(15.7)\end{array}$ \\
\hline $\begin{array}{l}\text { Industrial and } \\
\text { Artisans }\end{array}$ & $\begin{array}{l}\text { - Include organized cottage industries and } \\
\text { artisans. }\end{array}$ & $525(1.1)$ & $10,701(0.2)$ \\
\hline Producers & & & \\
\hline Mining & $\begin{array}{l}\text { - Associations involved in the small-scale } \\
\text { mining and marketing of different items } \\
\text { including gold, salt and other minerals. }\end{array}$ & $761(1.6)$ & $24,052(0.4)$ \\
\hline $\begin{array}{l}\text { Housing and } \\
\text { Construction }\end{array}$ & $\begin{array}{l}\text { - Mainly organized in urban and suburban } \\
\text { areas for different purposes (to solve their } \\
\text { own housing problem, to produce and } \\
\text { supply construction materials such as } \\
\text { bricks, and to involve in other construction } \\
\text { industries including rural roads). }\end{array}$ & $8,452(17.6)$ & $\begin{array}{r}166,957 \\
(2.5)\end{array}$ \\
\hline Other services & $\begin{array}{l}\text { - The main target of the members of these } \\
\text { associations is to support themselves } \\
\text { economically in organized and effective } \\
\text { ways. Examples: animal marketing and } \\
\text { slaughtering service, skins and hides } \\
\text { marketing, public transport and carts } \\
\text { owner associations, etc. }\end{array}$ & $657(1.4)$ & $9,971(0.6)$ \\
\hline Others & - Uncategorized associations. & $9,989(20.8)$ & $\begin{array}{r}535,099 \\
(8.1) \\
\end{array}$ \\
\hline Total & & $48,124(100.0)$ & $\begin{array}{r}6,635,458 \\
(100.0) \\
\end{array}$ \\
\hline
\end{tabular}

Source: Computed based on data from FCA (2013)

In line with the formulation and implementation of different rural development policies and strategies as indicated earlier, modern cooperatives in Ethiopia have been expanding at a fast rate in terms of both 58 
number and capital. When the first proclamation of the EPRDF regime was introduced in 1994, only limited active rural and urban cooperatives, which were established during the Derg regime, were present. Though some of these rural cooperatives were reorganized, following proclamation No. $85 / 1994$, the biggest increase followed the enactment of proclamation No.147/1998. The government plan to expand cooperatives by establishing at least one primary cooperative in each village and one union per district has also further enhanced the development of cooperatives (Emana 2012). As a result, the total number of cooperatives increased by about $64 \%$ between 2006 and 2013 (Figure 1). In general, the longitudinal analysis of the total number of cooperatives shows an increasing trend over time (Figure 1).

Similarly, Table 2 shows the total number of primary cooperatives of all regional states at the end of 2013 being about 56,044 with about 9.2 million individual members. This number of cooperatives has risen to more than 60,000 in 2015. More than 2.2 million (24\%) of the cooperative members were also women, the number showing an increasing trend. The Oromia region is the largest in terms of number of members and primary cooperatives, and second largest in capital (next to Addis Ababa). As a whole, cooperatives have been increasing in terms of both number and capital in all regions. 


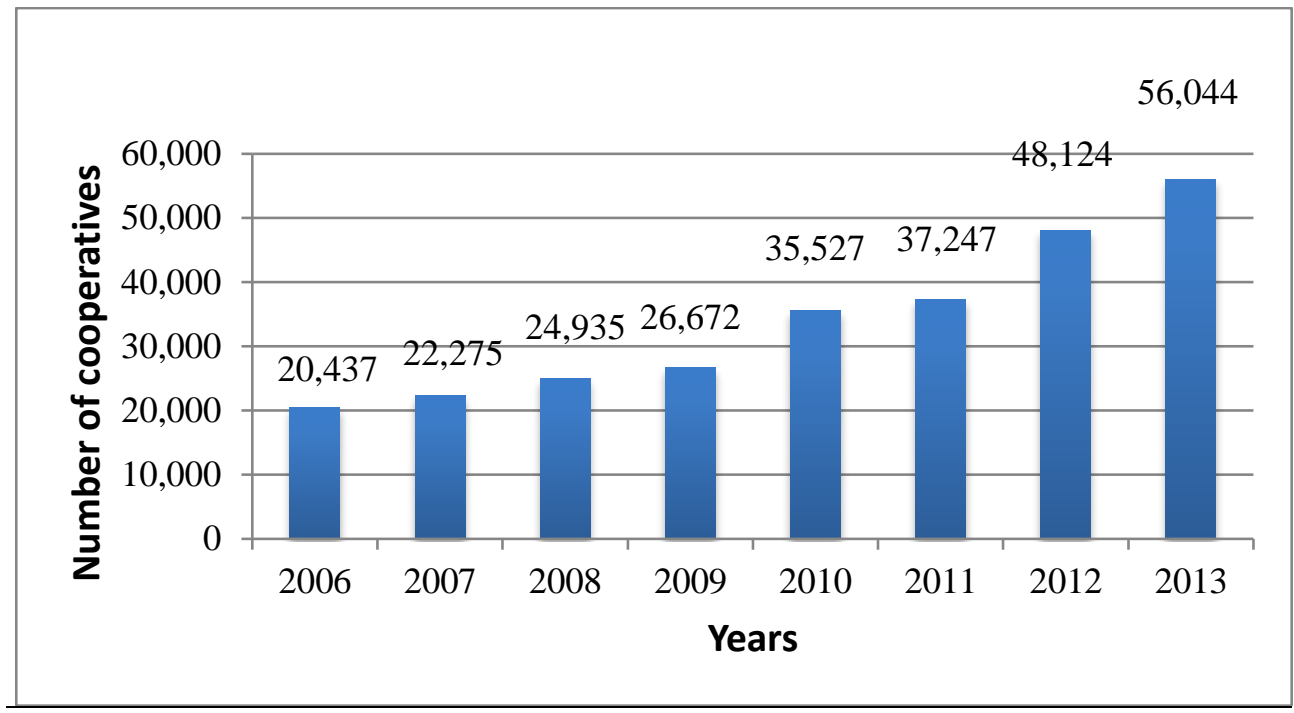

Figure 1. The trends and status of primary cooperatives (2006-2013)

Source: Computed using data from FCA database (FCA 2014b)

Table 2. Status of Cooperative Societies by region, sex of members and capital

\begin{tabular}{|c|c|c|c|c|c|c|}
\hline \multirow{2}{*}{ No. } & \multirow{2}{*}{$\begin{array}{l}\begin{array}{l}\text { Regional } \\
\text { states }\end{array} \\
\end{array}$} & \multirow{2}{*}{$\begin{array}{l}\text { Number of } \\
\text { coops }\end{array}$} & \multicolumn{3}{|c|}{ Number of members } & \multirow{2}{*}{$\begin{array}{l}\text { Capital } \\
(\text { ETB*) } \\
\end{array}$} \\
\hline & & & Men & Women & Total & \\
\hline 1 & Dire Dawa & 201 & 5,994 & 7,877 & 13,871 & $4,336,865$ \\
\hline 2 & Harari & 178 & 6,335 & 4,705 & 11,040 & $8,246,881$ \\
\hline 3 & $\begin{array}{l}\text { Benshangul } \\
\text { Gumuz }\end{array}$ & 349 & 11,977 & 10,217 & 22,194 & $17,153,085$ \\
\hline 4 & Gambela & 516 & 6,888 & 4,785 & 11,673 & $18,992,021$ \\
\hline 5 & Afar & 777 & 18,223 & 9,470 & 27,693 & $23,993,029$ \\
\hline 6 & Somale & 1,821 & 28,136 & 18,532 & 46,668 & $90,255,720$ \\
\hline 7 & Tigray & 4,539 & 583,002 & 232,253 & 815,255 & $766,960,753$ \\
\hline 8 & Amhara & 7,412 & $2,161,646$ & 678,724 & $2,840,370$ & $730,313,611$ \\
\hline 9 & SNNP & 11,702 & $1,126,649$ & 297,844 & $1,424,493$ & $746,448,895$ \\
\hline 10 & Addis Ababa & 12,130 & 462,276 & 478,715 & 940,991 & $5,014,148,620$ \\
\hline \multirow[t]{2}{*}{11} & Oromia & 16,419 & $2,538,463$ & 472,556 & $3,011,019$ & $1,334,726,531$ \\
\hline & Total & 56,044 & $6,949,589$ & $2,215,678$ & $9,165,267$ & $8,755,576,011$ \\
\hline
\end{tabular}

Note: $*$ ETB is Ethiopian currency, 1 USD $=20$ ETB during study period.

Source: FCA 2014a. Cooperatives. Annual publication 1(11), 2014. 


\section{Some highlights on the Impacts of Agricultural Cooperatives in Ethiopia}

In Ethiopia, the agricultural sector generally accounts for about $40 \%$ of the Gross Domestic Product (GDP) (NBE 2014) and is dominated by smallholder farmers who remain important for economic development and poverty reduction. Yet, agricultural land degradation and deforestation, drought and unreliable weather, poor infrastructure and market imperfection are among important problems constraining the agricultural sector and rural livelihood development. Agricultural cooperatives, among others, are premeditated to overcome these constraints through rendering many services such as input/output marketing, expanding financial services in rural areas, purchasing agricultural machinery, equipment and implements and leasing them to farmers as well as establishing small agroprocessing industries (FDRE 1998). They are also expected to establish various social institutions to provide different social services. Based on the existing literature and data obtained from the FCA, some examples of the economic, social and environmental impacts of agricultural cooperatives in Ethiopia are assessed and presented as follows.

\section{Economic Impacts}

Evidences indicate that cooperatives in Ethiopia have been creating enormous socioeconomic benefits to members through distributing agricultural inputs, providing improved technologies, and encouraging farmers to produce high value crops. For instance, cooperatives imported and distributed a total of 906,220 tons of fertilizers from 2005-2008, which is about $70 \%$ of the total fertilizers the country imported each year (FCA 2014a). The same source shows that although cooperatives have not been directly importing fertilizers since 2009, they have been distributing $95 \%$ of the fertilizers imported through a centralized Agricultural Input Supply Corporation (AISCO); and they distributed 692,781 tons of fertilizers in 2013/14 alone. Generally, compared to private traders, input supply through cooperatives has created an easy access to the farmers at a reasonable price (Emana and Nigussie 2011).

In addition, cooperatives are involved in the distribution of improved seeds, farm implements (such as water pumps), pesticides and herbicides, modern beehives and other agricultural inputs. For instance, in the 2012/13 cropping season, cooperatives distributed about 110,578.4 tons of improved seeds of different types (FCA 2014a). Moreover, they also play important roles in nonagricultural input supply such as construction materials, and consumable and agricultural products in a good quality, quantity, and at reasonable prices.

Cooperatives are also involved in output marketing, creating market opportunities and in serving as a market channel. Coffee, sesame, grains, animal 
products, milk and milk products are among the main agricultural products that they have successfully marketed. For example, seven coffee cooperative unions exported about 6,967 tons of coffee and generated revenue of about 24 million USD in the year 2007. This raised the export to 11,532 tons of coffee (generated about 76 million USD) in 2013 (FCA 2014a). FCA data also show that over the period of 2009-2013, cooperatives supplied, on average, about 2.5 million tons of grain; 11.7 million litters of milk; 124,404 live animals; 17,356 quintals of fish; and 21,141 quintals of honey per year to the market and improved members' income.

Cooperatives have also been paying higher prices to members and maintaining the price of floor for the commodities they market. The presence of cooperatives has by large created competitive markets and protected the producers, and even benefited non-member farmers (Emana and Nigussie 2011).

Other important economic benefits of cooperatives are direct and indirect employment opportunities created for many individuals. This could also be considered as a social benefit. As FCA (2013) data indicate, about 12,902 cooperatives created direct employment opportunities to over 623,950 members and to 181,133 non-members. Hence, cooperatives have generated more than 805,053 jobs throughout the country.

Some cooperative unions have also been engaged in product processing and value addition, thereby economically benefiting their members. A good example in this case includes Liche Hadiya and Lume Adama cooperative unions that have been involved in value addition through processing (FCA 2014a). According to FCA, cooperatives have been playing important roles in economic benefits, ensuring a fair share of resources, and reducing income disparity.

Several empirical studies that analysed the economic impact of agricultural cooperatives in different parts of Ethiopia and elsewhere also indicate an overall positive contribution of cooperatives to rural development and poverty reduction efforts. However, the results are inconsistent, location-specific and vary with the nature of cooperatives (see Kodama 2007, Bacon et al. 2008, Emana 2009, Getnet and Anullo 2012, and Mojo et al. 2017). Additionally, some studies show low participation of members in cooperatives (Anteneh et al. 2011 and Bernand et al. 2013) and suggest a need for updating information regarding the economic benefits of cooperatives since low participation could be due to low benefits of cooperatives to the members. In fact, a recent study conducted to assess the economic impact of coffee farmer cooperatives in Ethiopia indicate that the low participation of cooperatives could be attributed to the undifferentiated services of cooperatives, i.e., cooperatives provide similar marketing and non-marketing services to both members and non-members (Mojo et al. 2015a). 


\section{Social Benefits}

Different reports, such as Emana and Nigussie (2011) and FCA (2015) indicate that agricultural cooperatives also perform a wide range of social activities. They contribute to the development of community health by providing training on family planning, HIV prevention, and on personal and environmental hygiene. They also involve in building public infrastructure, such as health centres, clean water, schools, roads, bridges, etc. They support the youth, children and women, the homeless and disabled individuals and ensure their participation in the economy. Cooperatives also participate in awareness creation, provision of good social protection for employees and in creating a joint voicing mechanism for the rural and scattered people.

The economic benefits of cooperatives discussed earlier have also their share in contributing to social benefits, as the income earned from cooperatives could be invested in children's education and cover health expenses. Furthermore, as service provision being one of the objectives of cooperatives, both primary cooperatives and cooperative unions (should) spend about 5\% of their profits as investment in social services (EPRDF 1998). This has also long-term economic benefits to the cooperatives, since it can help to increase the social capital of the community. Some empirical studies also indicate that cooperatives have significantly positive impact in creating social and human capital (Majee and Hoyt 2010; Mojo et.al. 2015b). Despite their potential however, only a few cooperative unions are currently undertaking such activities of contributing to the social wellbeing.

\section{Natural Resources Management and Environmental Benefits}

Agricultural cooperatives are, in nature, organizations that engage in natural resource management activities, environmental protection and care for the community. They are expected to provide financial and material support for environmental protection, soil and water conservation, forest, wildlife, water and air protection activities. Despite the expected all-around roles of cooperatives potential organizational vehicles for sustainable development (Wanyama 2014), both qualitative and quantitative studies are scanty regarding the environmental impacts of cooperatives in Ethiopia.

Nevertheless, some studies report that cooperatives have been negatively contributing to environmental sustainability in Ethiopia (Stellmacher and Grote 2011 and Mojo, et al., 2015b). These authors argue that improvements in farm gate prices (due to better markets created by cooperatives) motivate the farmers to further increase their yields through intensifying production encroaching onto forestlands and consequently utilizing the natural resource unsustainably. Conversely, cooperatives should not only be economically viable and socially equitable, but also environmentally sustainable so long as they are guided by principles of the International Cooperative Alliance. Furthermore, Rodrigo (2013) 
reported that cooperative participation reduced adoption of soil and water conservation practices in some parts of Ethiopia, due to the nature of the technologies that require fixed investment the cooperatives fail to promote. On the other hand, a study by Blackman and Naranjo (2012), focusing on Costa Rican certified coffee cooperatives, reported an improvement in coffee growers' environmental performance, i.e. cooperative members reduced the use of chemical inputs and increased the adoption of environment-friendly practices. Hence, the impacts of cooperatives on environment may also need to be studied further in the future based on the aforementioned mixed findings.

\section{Strengths, Weaknesses, Opportunities of and Threats to the Cooperative Development}

Some studies (Emana and Nigussie 2011; Alemu et.al. 2011 and FCA 2015) have analysed the strengths, weaknesses, opportunities, and threats (SWOT) of cooperatives in Ethiopia. The summary of this SWOT analysis is given in Table 3. It is shown that while cooperatives have been strong in providing services to the members and community at fair prices, they were not free of weaknesses in leadership/management and in the capability and commitments of members. On the other hand, government commitment in supporting cooperatives, establishing legal ground and infrastructure development as well as availability of various development partners were considered as opportunities for cooperative development. However, the interferences of the government and other development partners in decision making on matters of cooperatives, unauthorized intrusions and the use of cooperatives for political purposes by local governments, absence of an established exit strategy by cooperative initiators, etc. have been identified as serious threats to the cooperative development in Ethiopia. 
Table 3. Strengths, weaknesses, opportunities and threats (SWOT) of Ethiopian cooperatives

\section{Internal factors \\ Strengths \\ - Supply agricultural inputs at fair prices; \\ - Enable members to get higher prices for outputs; \\ - Create market alternatives/ serve as competitors with private traders;}

- Create economic benefits for members through entering into value addition process.

\section{External factors}

\section{Opportunities}

- Government special attention and support to cooperatives;

- Presence of oversight/regulation structures from federal down to district level;

- Government special emphases to infrastructure development that can ease cooperative access to market;

- The current high demand of agricultural products that can create an opportunity for cooperatives to increase their capital;

- Availability of training colleges and universities specialized in cooperatives;

- Availability of different development collaborates (NGOs and government organizations) that can enhance cooperative performance.

\section{Weaknesses}

Management-related:

- Weak leadership and management capacity;

- Limited capacity to use modern technologies;

- Lack of transparency of cooperative management bodies;

- Limited budget and unwillingness to higher professional managers of cooperatives;

\section{Threats}

- Lack of comprehensive cooperative policy and strategy document, and inconsistency between national and regional cooperative society proclamations, rules and regulations;

- Inconsistency between cooperative bylaws and local practical situation, in some cases;

- Absence of fully fledged cooperative promotion package and extension system;

- Absence of regular audit, inspection and monitoring services;

- Unstable institutional setting of the cooperative 


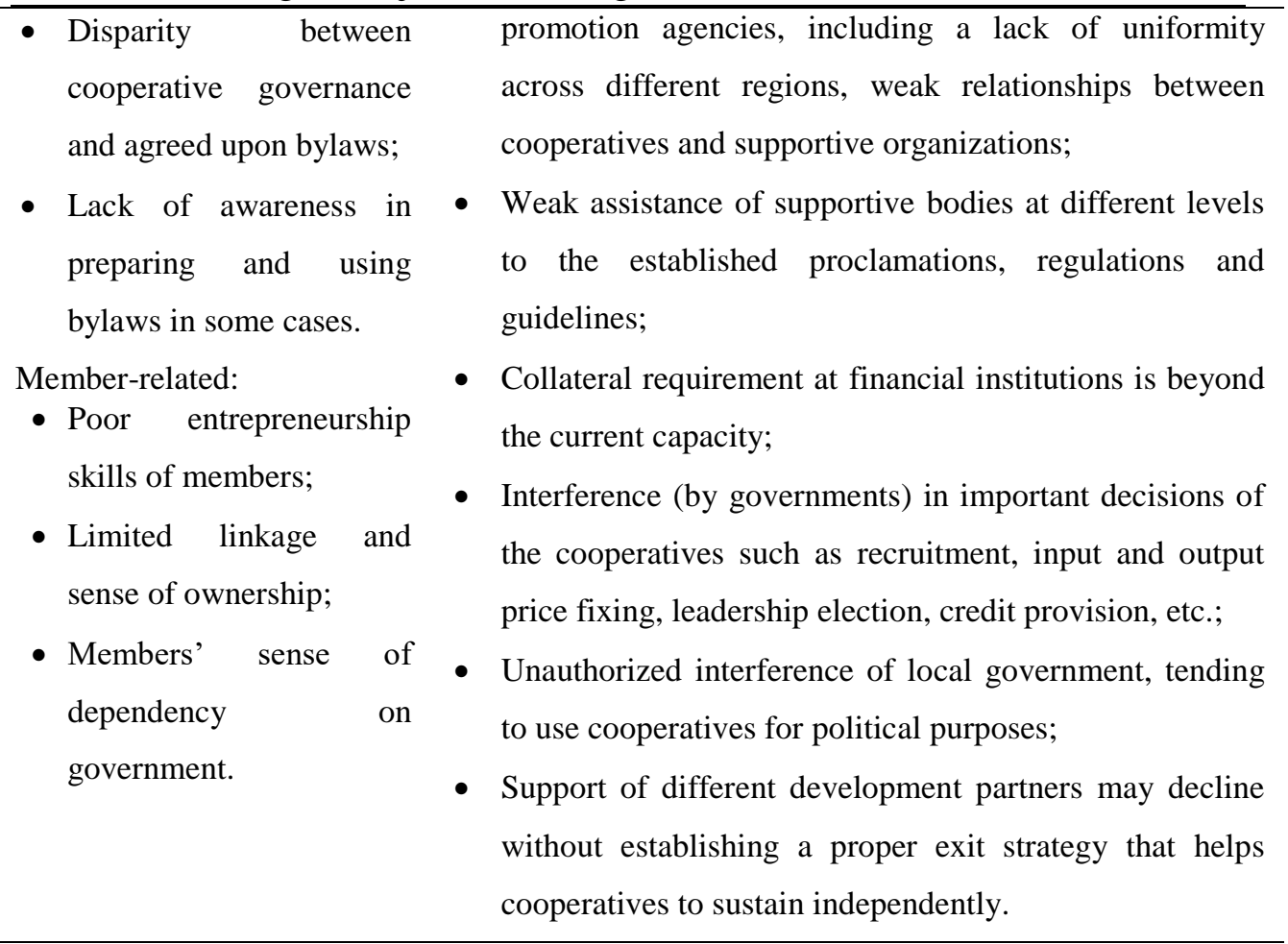

Source: Summarized from Emana and Nigussie (2011), Alemu et.al. (2011), and FCA (2015)

\section{Building Sustainable Agricultural Cooperatives in Ethiopia: A Framework for Future Use}

Sustainable development is a global essential phenomenon that both developed and developing countries have embraced and promoted since the World Commission's report - Our Common Future - of 1987. Business organizations are also being asked to apply sustainability principles ${ }^{6}$ to the ways in which they conduct their business (D'Amato et al. 2009). In fact, sustainability in business was traditionally

\footnotetext{
${ }^{6}$ The core sustainability principle (aka sustainable development) is 'meeting the needs of the present generation without compromising the ability of the next generations to meet their own needs' (WCED 1987). The popularity of the word sustainability came from the phrase 'Sustainable Development' that the World Commission on Environment and Development (WCED) broadly framed in its report of 1987 that aimed to identify the causes and remedies of development failures. The study proposed that the development should consider intra- and inter-generation equity - which was further framed into environmental, economic and social dimensions of sustainability.
}

66 
a parameter on the corporate and social responsibility agenda, due to moral obligation, reputational risk or regulatory requirements. Since the notion of sustainable development came in to existence, these parameters have grown from an original focus on economic and social dimensions to including ecological aspects (Rapacioli et al. 2011). This inclusion of social, economic and ecological aspects into a business transformed the traditional net-income based performance evaluation to sustainable performance evaluation, i.e. a shift from a single-bottomline to a triple-bottom-line approach. Consequently, over the last few decades, many enterprises, including some cooperatives (e.g. Canadian Cooperative Associations, UK Cooperative Groups, etc.) have been reporting the sustainability performance of their enterprises using different sustainability reporting frameworks, such as Global Reporting Initiatives (GRI). Among other business models, the cooperative model that puts people at the centre (instead of capital) has been typified as an appropriate one for sustainability (Toit and Buys 2013).

The aim of this article is, therefore, not only limited to reviewing the development of agricultural cooperatives in Ethiopia, but also proposing the social, economic and environmental considerations when establishing agricultural cooperatives, and evaluating their performance and impacts in due course of time. Hence, the article puts forward a potential sustainability planning, monitoring, and evaluation (SPME) framework (Figure 2) that includes the elements to be considered when establishing, monitoring, and evaluating agricultural cooperatives in Ethiopia and beyond. If we really need to enhance sustainable development, we need to exercise integrating sustainability principles in every organization, including cooperatives, beginning from the planning stage. If cooperatives perform well, their impacts could be reflected on members' (economic, environmental and social) performance.

The SPME framework which is suggested here consists of two main components (performance determinants and performance indicators) identified based on institutional economics theory, literature on sustainability indicators, and sustainability reporting frameworks such as Global Reporting Initiatives (GRI) (Toit and Buys 2013) and Sustainability Balanced Scorecard (SBSC) (Figge et al. 2002).

\section{Determinants of Cooperative Performance}

As indicated earlier, the first component of the proposed SPME framework contains factors that determine performance of cooperatives. To build a sustainable cooperative, what needs to be of great importance is giving due consideration to the structure (institutional arrangement) of the cooperative per se. That is, we need to ensure that cooperative policies, regulations, bylaws and norms allow or require 
the consideration of sustainability principles in each activity. Institutions ${ }^{7}$ are referred to as 'rules of the game' (North 2005), and several studies present good institutional arrangement as the most important factor for sustainable development of a country in a broader sense, and for the performance of an organization in a specific one. Institutional arrangement is a design which is highly important to sustainability since a wrong initial design often leads to a failure. What makes institutional arrangements good or bad is a wide topic by itself, and reviews can be found in several studies, such as Williamson (2009). In any case, rules that target all social, economic, and environmental aspects should be in place, i.e. revising the current Ethiopian cooperative model, which mainly focuses on socioeconomic aspects, may be needed.

Furthermore, even though different cooperatives are using the same institutional arrangement, their performance could be different, due to internal processes (factors) that include planning, governance ${ }^{8}$, and participation of the members and staff. In addition, performance is also affected by external processes, including relationships with governmental and non-governmental organizations, other stakeholders, market structure, etc. (Figure 2), implies that good institutional arrangement by itself may not lead to sustainable performance. Hence, cooperative structures, internal and external factors together affect cooperative (social, economic, and environmental) performance and need to be considered in unison. Interaction among these factors can also generate a feedback loop for further improvement of the structures of cooperatives, as shown in Figure 2 (upward arrows).

\section{Sustainable Performance/Impact Evaluation}

The second component of SPME framework focuses on evaluating the performance and impacts of cooperatives based on measurable indicators. To assess whether cooperative performance is sustainable, the social, economic, and

\footnotetext{
${ }^{7}$ In the literature, institutions are referred to as norms, rules (formal or informal), conventions, habits and values that regulate social behavior; or in short, 'the humanlydevised constraints that structure human interaction' (North 1990 and Chibanda et al. 2009). An institution also consists of cognitive structures - that shape meaning, normative structures - that prescribe behaviors and regulative structures - that constrain behaviors. Institutional arrangements are simply the combination of formal constraints, informal rules, and their enforcement characteristics (North 2005 and Williamson 2009).
}

${ }^{8}$ Governance is the process of decision-making and process of implementing the decisions (Huther and Shah 2005). The quality of governance is usually characterized in terms of being: participatory, consensus oriented, accountable, transparent, responsive, effective and efficient, equitable and inclusive, and following the rule of the law (UNESCAP 2013). Governance is also intern affected by several factors such as a leadership quality.

68 
environmental indicators should be identified under each category. These indicators shall be measured over time and need to show the changes/progress that the cooperatives have made. Existing sustainability reporting frameworks, such as Global Reporting Initiatives (GRI) can be applied to measure progress of cooperatives at this stage.

Cooperative performance can also be reflected in its impact on members' (social, economic and environmental) performance. These impact evaluations can be made through different approaches, such as by comparing before and after program situations, or by comparing the performance of cooperative members with that of non-members. The performance of cooperatives and their impacts are complimentary but are not necessarily the same. Performance usually looks at the cooperatives themselves, while impact is about effects on the other parties (e.g. on members' income) assessed using appropriate indicators.

Finally, the SPME framework shows that every sustainable social, economic and environmental move (impact) made should positively contribute to sustainable development. Normally, when integrating the concept of sustainability, cooperatives should develop strategies that will lead to the creation of social, environmental, and economic values, and the SPME framework may help as a guide regarding what to consider during planning, monitoring, and evaluation. Meanwhile, the weakness of cooperatives underlined earlier can be corrected if this framework is adopted. 


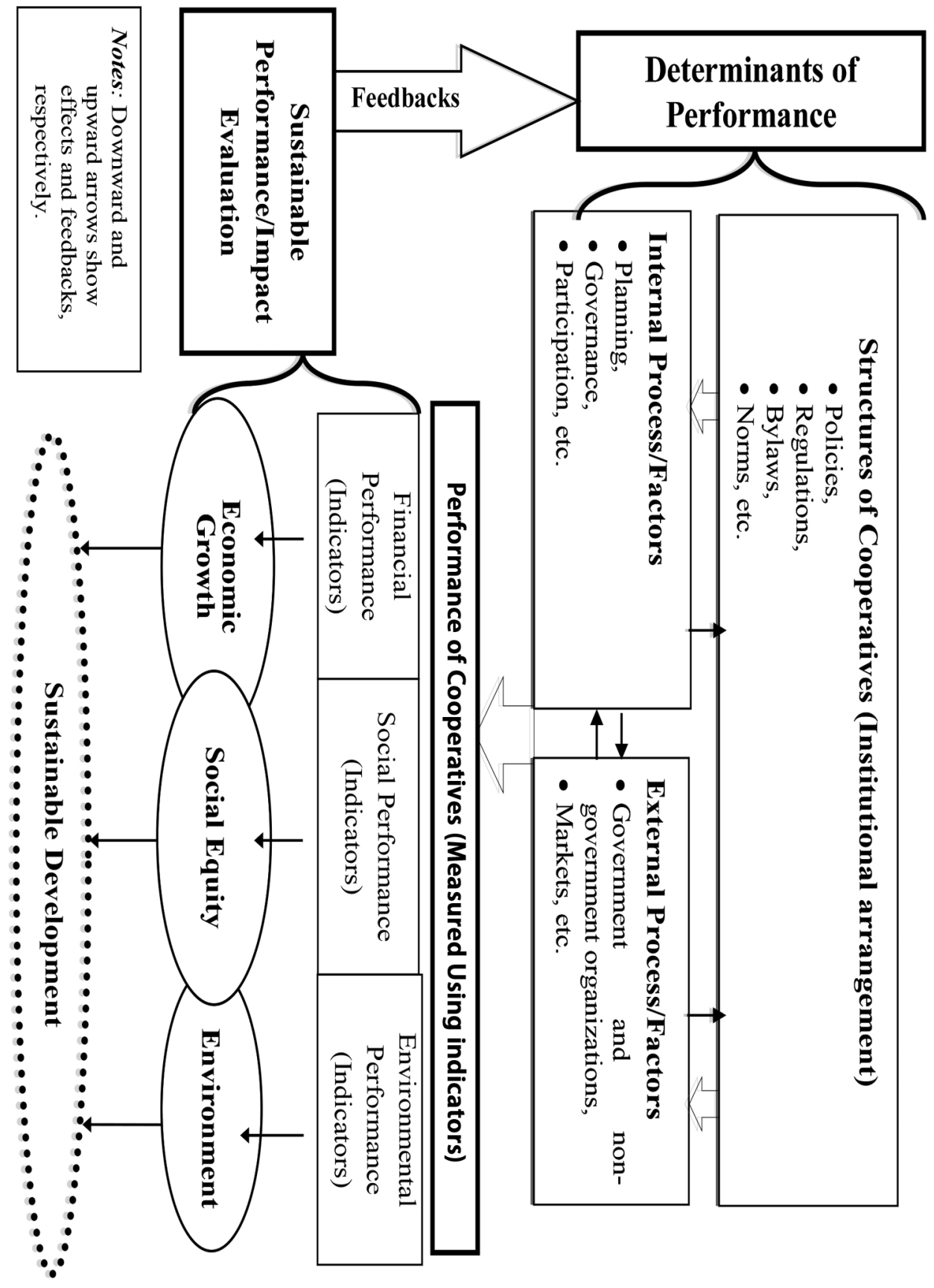


Figure 2. Sustainability Planning, Monitoring, and Evaluation (SPME) Framework i.e. developed based on theories and reviews of literature mentioned in the text (please see the previous page).

\section{Application of the SPME Framework}

As its name indicates, the SPME framework can be applied to design a sustainable cooperative at establishment (since it can serve as a guide in identifying what determines cooperative performance), and also helps to monitor and evaluate the performance or impact of any cooperative. Even if a cooperative was not designed using this framework, it can still help to assess the strengths and weaknesses of the existing cooperative model.

Considering the above, it is possible to pinpoint the lessons learned from previous studies and identify whether the findings could locate what went wrong/right according to the SPME framework. For instance, findings about members' low participation and some problems with property rights and governance (Bernard et al. 2013 and Mojo et.al. 2015a) indicate weaknesses in the internal and external processes as well as the structure of cooperatives as a whole. Hence, enriching the capacity of leaders, enabling the managing committees and members to exercise cooperative principles and obeying the agreed-upon bylaws, or modifying the cooperative rules (i.e. working on structures and internal processes) could be suggested. And, doing so could make the cooperative movement in the country more vigorous and sustainable.

Another good example could be a study that reported some undifferentiated services of cooperatives to members and non-members (Mojo et.al. 2015a and Mojo et.al 2017), which might have resulted in low participation of members. This problem can be addressed by improving cooperative structures (such as by strengthening bylaws) and improving internal processes (governance). Hence, the problems can easily be located and actions can be taken if the SPME framework is employed. Furthermore, the studies that indicate important positive impacts of cooperatives on farmers' social performance (Mojo et.al. 2015b and Mojo et.al. 2016) highlight positive activities in the internal processes that have to be strengthened further. In the meantime, the negative impact of cooperatives on the environment suggests for a need to revise the cooperative structure and internal and external processes. In general, it is possible to locate what is going well and what should be improved to make progress toward sustainable development using the proposed framework. In addition, if 
future cooperatives are designed considering sustainability principles, sustainable performance evaluations would be made easier.

\section{Conclusions and Future Trajectory}

This article has presented the reviews of the cooperative movement in Ethiopia and proposed a framework for future use. The evolution of the modern cooperative societies, the economic, social and environmental benefits as well as their SWOT analysis have been discussed based on related literature and analysis of secondary data.

The article has brought to light the fact that modern cooperatives in Ethiopia have undergone different changes since the formal introduction back in the early 1960s and are now in their third generation. Due to differences in the political ideology of the past regimes, cooperatives had been changing and were used as tools for the implementation of government policies irrespective of international cooperative principles. It was only after the 1990s that some room has been opened to exercise at least some of the basic cooperative principles such as voluntariness and open membership.

Recently, because of strong government promotion and support (both institutionally and technically), the number of cooperatives has increased at a fast rate (66\% over the last 8 years), and their capital has grown reciprocally. The benefits of agricultural cooperatives, particularly, are also significant in many aspects. However, while there are several opportunities for and strengths of cooperatives in Ethiopia, serious weaknesses and threats exist, which could be challenges for their future/sustained existences and benefits. The major challenges are related to legal frameworks, inadequate market regulations and policies, free-rider problems, and poorly developed managerial practices (not based on scientific evidences and skills) that cooperatives have adopted. Additionally, the current negative impacts of cooperatives on environment that are reported by different studies are also a challenge that cooperatives should overcome to ensure a positive contribution to sustainable development.

As long as government offices (i.e., FCA) continue promoting cooperatives, the numbers of cooperatives will keep on growing. It could be nonetheless necessary to start working on mechanisms to ensure the sustainability of the cooperatives. It is time to raise questions like, how many of these cooperatives can continue functioning if the government (or NGOs) assistances are halted? Have government institutions, such as the 
FCA, enriched the capacity of cooperative leaders? To what extent do managing committees and members obey cooperative rules and their own agreed upon bylaws? Do cooperatives take environmental sustainability into account, or focus on the socioeconomic services alone? And similar painstaking questions should be raised and answered so as to help the cooperative movement in the country to be long-lasting.

The existence of cooperatives in the business environment usually depends on many factors, which include leadership, type of cooperatives, market linkages, investments in fixed assets (that can be used as collateral), location, initial establishment, member size, access to capital and the availability of sound technical support systems, among others (Emana and Nigussie 2011). As economic viability of cooperatives alone does not insure their existence, working on ensuring equity, equality and social sustainability as a whole becomes vital. Moreover, to be competitive, all cooperative societies should place environmental sustainability as integral part of their activities since the world is getting more conscious about the environmental cost of doing business. Generally, taking the variations of challenges regarding the performance of cooperatives by type for granted, the next concern in cooperative business in Ethiopia is about their own existence and their staying competitive in this changing world.

Hence, the proposed SPME framework can be used as a guide when initiating a cooperative in the future and can help to integrate sustainable development principles into a cooperative structure right from the setup stage. Moreover, the SPME framework can help to indicate how a cooperative can contribute to the economy, society and environment in activity plan upon which its performance can be monitored and evaluated. The framework can also help to revisit and evaluate the current cooperative structure to make the necessary amendment.

Generally, this article embraces important implications and can also be a foundation in promoting the performance/impact evaluations of cooperatives from economic, social, and environmental perspectives as these are minimum criteria to be met for a sustainable development. 


\section{References}

Abebaw, D., and M.G. Haile. 2013. "The Impact of Cooperatives on Agricultural Technology Adoption: Empirical Evidence from Ethiopia." Food Policy, (38): 82-91.

Alemu, G., 2012. Rural Land Policy, Rural Transformation and Recent Trends in Large-Scale Rural Land Acquisitions in Ethiopia. Addis Ababa: Addis Ababa University.

Alemu, D., T. Anullo, B. Tesfaye, A. Hagos, A. Feyisa. 2011. Cooperative Society Movement in Ethiopia: Accomplishment, Problems and Alternative Solutions of Cooperative Society and Supportive Organs. Addis Ababa: Ethiopian Institute of Agricultural Research.

Anteneh, A., R. Muradian, R. Ruben. 2011. Factors Affecting Coffee Farmers Market Outlet Choice: The Case of Sidama Zone, Ethiopia. Paper Presented at EMNet Conference December 1-3. Limassol, Cyprus: Frederick University.

Asrat, D., A. Shiferaw. 2009. Law of Public Enterprises and Cooperatives. Addis Ababa: Justice and Legal System Research Institute.

Bacon, C.M., V.E. Méndez, M.E.F. Gómez, D. Stuart and S.R.D. Flores. 2008. "Are sustainable coffee certifications enough to secure farmer livelihoods? The millennium development goals and Nicaragua's Fair Trade cooperatives." Globalizations, 5 (2): 259-274.

Bernard, T., G.T. Abate and S. Lemma. 2013. Agricultural Cooperatives in Ethiopia: Results of The 2012 ATA Baseline Survey. Washington (DC): International Food Policy Res. Retrieved from http://ebrary.ifpri.org/cdm/ref/collection/p15738coll2/id/127690

Bernard, T., D. Spielman, A.S. Taffesse, E. Gabre-Madhin. 2010. Cooperatives for Staple Crop Marketing: Evidence from Ethiopia. (Vol. 16). Washington, DC: Intl Food Policy Res Inst.

Blackman, A. and M.A., Naranjo. 2012. "Does eco-certification have environmental benefits? Organic coffee in Costa Rica."Ecol Econ, 83: 58-66.

Chibanda, M., G.F., Ortmann, M.C., Lyne. 2009. "Institutional and governance factors influencing the performance of selected smallholder agricultural cooperatives in KwaZulu-Natal."Agrekon, 48 (3): 293-306.

D'Amato, A., S. Henderson, S. Florence. 2009. Corporate social responsibility and sustainable business. Greensboro, North Carolina: Center for Creative Leadership.

Emana, B. 2009.Cooperatives: A Path to Economic and Social Empowerment in Ethiopia. Coop AFRICA (Working Paper No. 9). Dar es Salaam: International Labor Organization (ILO).

Emana, B. 2012. Cooperative movement in Ethiopia (a Paper Presented at Workshop on Perspectives for Cooperatives in Eastern Africa) Uganda: Kampala. 
Emana, B., M. Nigussie. 2011. Strategizing Cooperative Development in Ethiopia. (An Unpublished Report Submitted to Agricultural Transformation Agency (ATA)). Addis Ababa, Ethiopia.

Federal Cooperative Agency (FCA). 2013. Unpublished data, Addis Ababa, Ethiopia.

Federal Cooperative Agency (FCA). 2014a. Cooperatives. Annual publication 1(11), Addis Ababa: FCA.

Federal Cooperative Agency (FCA). 2015. Achievements, Challenges, and Future Directions of Ethiopian Cooperative Movements. Addis Ababa: FCA.

Federal Cooperative Agency FCA(FCA).2014b. Unpublished data, Addis Ababa, Ethiopia.

Federal Democratic Republic of Ethiopia (FDRE). 1998. Establishment of Cooperative Societies, Proclamation No. 147/1998. Addis Ababa: Federal Negarit Gazeta.

Figge, F.,T. Hahn, S. Schaltegger, M. Wagner. 2002. The sustainability balanced scorecard-linking sustainability management to business strategy. Business Strategy and the Environment, 11(5): 269-284.

Gebre-selassie, A., T. Bekele. 2012. A review of Ethiopian agriculture: roles, policy and small-scale farming systems. In Eder, C., Kyd-Rebenburg, D. and Prammer, J., editors. Global Growing Casebook - Insights into African Agriculture (Global Growing Campaign). Retrieved from http://globalgrowing.org

Getnet, K., and T. Anullo. 2012. "Agricultural cooperatives and rural livelihoods: evidence from Ethiopia." Annals of Public and Cooperative Economics, 83 (2): 181-198.

Holmberg, S.R. 2011. Solving the Coffee Paradox: Understanding Ethiopia's Coffee Cooperatives through Elinor Ostrom's Theory of the Commons (Dissertation). Amherst: University of Massachusetts.

Huther, J. and A. Shah. 2005. "A simple measure of good Governance" in A., Shah, editor. Public Service Delivery. Washington D.C: The World Bank.

International Cooperative Alliance (ICA). 2014. Co-operative identity values and principles. Retrieved from http://ica.coop/en/whats-co-op/co-operativeidentity-values-principles

Kodama, Y. 2007. "New Role of Cooperatives in Ethiopia: The Case of Ethiopian Coffee Farmers' Cooperatives." African Study Monograph, 35: 87-08.

Lemma, T. 2009. Growth without Structure: The Cooperative Movement in Ethiopia. Geneva: ILO and World Bank institute.

Majee, W. and A. Hoyt. 2010. "Are worker-owned cooperatives the brewing pots for social capital? Community Development Journal, 41(4): 417-430. 
Mekonen, A. and D. Aredo, ed. 2000. Necessity and Neglect: Rural Local Organization and Rural Development in Ethiopia. Addis Ababa: Ethiopian Economic Association.

Ministry of Agriculture (MoA), Federal Democratic Republic of Ethiopia (2012). Agricultural Cooperatives Sector Development Strategy 2012-2016. Retrieved from: http://www.ata.gov.et/news/resources/sector-strategies/

Mojo, D., C. Fischer, T. Degefa. 2015b. "Social and environmental impacts of agricultural cooperatives: evidence from Ethiopia." International Journal of Sustainable Development and World Ecology, 22(5): 388-400.

Mojo, D., Fischer, C., and Degefa, T. (2015a). Who benefits from collective action? Determinants and economic impacts of coffee farmer cooperatives in Ethiopia. (Paper provided by International Association of Agricultural Economists in its series number 212708). Italy: Milan

Mojo, D., Fischer, C., and Degefa, T. 2016. "Collective Action and Aspirations: The Impact of Cooperatives on Ethiopian Coffee Farmers' Aspirations." Annals of Public and Cooperative Economics, 87(2): 217-238.

Mojo, D., C. Fischer, T. Degefa. 2017. "The determinants and economic impacts of membership in coffee farmer cooperatives: recent evidence from rural Ethiopia." Journal of Rural Studies, 50 (2017): 84-94.

National Bank of Ethiopia (NBE). 2014. Annual Report 2013/14. Retrieved from: http://www.nbe.gov.et/pdf/annualbulletin/Annual\%20Report\%2020132014/A nnual\%20Report\%202013-14new.pdf

North, D. 1990. Institutions, Institutional Change and Economic Performance. Cambridge: The University Press.

North, D. 2005. Understanding the process of economic change. Princeton: Princeton University Press.

Rodrigo, M.F. 2013. Cooperatives and Technology Adoption. Evidence from Ethiopia. Retrieved from:

http://www.aae.wisc.edu/events/papers/DevEcon/2013/rodrigo.04.11.pdf

Ruben, R., and J. Heras. 2012. "Social capital, governance and performance of Ethiopian coffee cooperatives." Annals of Public and Cooperative Economics, 83 (4): 463-484.

Stellmacher, T., and U. Grote. 2011. Forest Coffee Certification in Ethiopia: Economic Boon or Ecological Bane? (ZEF Working Paper Series 76). Bonn: ZEF.

Teka, B. 2011.Agricultural Cooperatives: Opportunities, Performances and Challenges: The Case of Adigudom Agricultural Cooperative Union in South Eastern Zone of Tigray. MSc Thesis. Addis Ababa University.

Toit, M. Du., and P.W. Buys. 2013. "An evaluation of the co-operative business model within the context of the Global Reporting Initiative. "International Business and Economics Research Journal, 12:179-192. 
United Nations Economic and Social Commission for Asia and the Pacific (UNESCAP). What is Good Governance? Retrieved from:

http://www.unescap.org/pdd/prs/ProjectActivities/Ongoing/gg/governance.asp Veerkumaran, G. 2007. Ethiopian Cooperative Movement: an Explorative Study. Mekele: Mekelle University, Department of Cooperatives.

Wanyama, F.O. 2014.Cooperatives and the Sustainable Development Goals: A Contribution to the Post-2015 Development Debate. Geneva (Switzerland): ILO.

Williamson, C.R. 2009. "Informal institutions rule: institutional arrangements and economic performance." Public Choice, 139(3-4): 371-387.

World Commission on Environment and Development (WCED) 1987. Our Common Future. Oxford: Oxford University Press. 